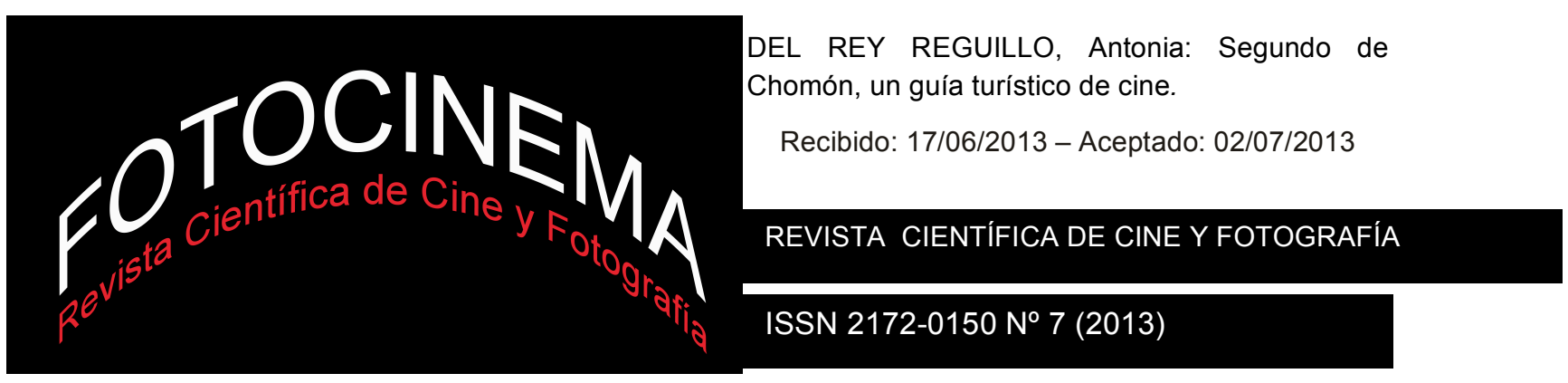

\title{
SEGUNDO DE CHOMÓN, UN GUÍA TURÍSTICO DE CINE*
}

\section{SEGUNDO DE CHOMÓN, A MOVIE TOURIST GUIDE}

\author{
Antonia del Rey-Reguillo \\ Universitat de València (España)
}

\section{Resumen:}

Desde sus orígenes el cine ha sido un poderoso creador de imaginarios sobre las culturas y los países del mundo. Por lo mismo, ha contribuido a configurar la imagen de España como destino turístico. Aunque los primeros documentales sobre España fueron filmados por camarógrafos extranjeros, muy pronto los operadores españoles empezaron a realizar sus propias películas, contribuyendo a conformar el imaginario fílmico nacional. Entre ellas destacan los documentales turísticos realizados para la firma Pathé por Segundo de Chomón, cuya habilidad narrativa y compositiva sientan las bases del género. Con ellos, sin obviar las expectativas espectatoriales, el cineasta consigue aportar un plus de realidad capaz de contrarrestar los habituales estereotipos sobre España manejados por el cine nacional e internacional coetáneos.

\begin{abstract}
:
Cinema has been, from the beginning, a powerful creator of imaginary about the cultures and countries of the world. For this reason, it has helped shape the image of Spain as a tourist destination. Although the first documentary about Spain were filmed by foreign cameramen, Spanish operators soon began making his own movies, helping to shape the national filmic imaginary. These include tourist documentaries made for the Pathé firm by Segundo de Chomón, whose narrative and compositional skills form the basis of documentary gender. With them, without forgetting spectatorial expectations, the filmmaker manages to provide an extra of veracity able to counteract the usual stereotypes about Spain handled by the national and international contemporary cinema.
\end{abstract}

\section{Palabras clave:}

Cine primitivo español; imaginario turístico sobre España; documental turístico; Segundo de Chomón

\section{Keywords:}

Spanish primitive cinema; tourist imaginary about Spain; tourist documentary; Segundo de Chomón.

\footnotetext{
* La redacción de este trabajo se ha realizado en el marco del proyecto de I+D (Ref. HAR201127750) La interacción entre el cine español de ficción y el turismo: desarrollo histórico-temático, claves culturales, políticas y económicas, que está financiado por el Ministerio de Economía y competitividad del Gobierno de España para el período 2012-2014.
} 


\section{Introducción}

La afición viajera que el cine practicó desde sus mismos orígenes, hizo que asumiera muy pronto su tarea de descubridor de mundos y la ejerciera de forma intensa con las llamadas "tomas de vistas" o filmaciones de lugares pensadas para engrosar los programas de "actualidades" ofrecidos al público a modo de noticiarios. Las "vistas", denominadas panoramas por los Lumière, films de plein air por la Pathé y la Gaumont y travelogues en el ámbito anglosajón, poseían un contenido temático implícito que apuntaba a la acción de ver y al disfrute de la visión del mundo y, en razón de ello, eran consumidas vorazmente por un público entusiasta. Con ellas, de forma impremeditada, el cine iniciaba una embrionaria estrategia de promoción turística al facilitar a los espectadores la experiencia de vivir una suerte de viaje a distancia mientras incorporaban a su imaginario las imágenes de lugares lejanos servidas desde la pantalla.

En realidad, la práctica cinematográfica de las tomas de vistas venía a reforzar la tarea de los promotores turísticos que desde mediados del siglo XIX habían emprendido la puesta en marcha de una industria que se vislumbraba como extraordinariamente rentable y que, en palabras de Monica Dall'Asta (1998, p. 247), había supuesto "la auténtica explosión de la cultura del viaje". Al respecto, la primera empresa de turismo, organizada por el británico Thomas Coock, había iniciado en 1841 sus primeros tours, con recorridos planificados en función del trazado de la red ferroviaria, al ser entonces el tren la forma de desplazamiento más segura y rápida. Unas décadas después, también el cine haría accesible el mundo a la mirada de los espectadores, aunque, en su caso, de forma virtual. En relación con esa capacidad, Anne Friedberg (1993) ha interpretado el sucesivo desarrollo de los medios de locomoción y el cine como un fenómeno inscrito en los procesos de cambio propios de la modernidad, que habrían culminado en un nuevo sistema perceptivo de la realidad fundado en la movilidad y la virtualidad de la mirada. 
Un buen porcentaje de las primeras tomas de vistas cinematográficas fue filmado en España por los camarógrafos extranjeros, con los franceses a la cabeza, que recorrieron el territorio español capturando con sus cámaras todo aquello que les parecía exótico o pintoresco. Sólo en el catálogo Lumière de 1896 figuran 45 vistas correspondientes a España y rodadas en Madrid, Sevilla y Barcelona (Gubern, 2004, p. 23-26). De esta forma, el cine empezaba a configurar su propia imagen de España, incorporándose así a una tarea que en épocas anteriores había sido privilegio casi exclusivo de los visitantes extranjeros. Desde siglos atrás, esos viajeros venían dejando testimonios escritos con valoraciones de todo orden sobre un país que para unos era cuando menos incómodo y, para otros, como el británico James Howell, "el más digno de ser visto después de Francia” (Barke \& Towner, 1996, pp. 3-34). Estos últimos, en su mayoría, fueron viajeros de espíritu romántico que, en sintonía con los nuevos gustos de su época, encontraron en la "extravagancia” y "diferencia” españolas, por usar los términos de Francisco Ayala (1986), un lado suficientemente salvaje y exótico como para entusiasmarse con ellas.

Con su admiración entusiasta hacia el país esos viajeros románticos crearon un estado de opinión internacional favorable hacia España que contribuyó a que en la segunda mitad del siglo XIX fuera incorporada al circuito turístico europeo, donde llegaría a ocupar el tercer lugar en el ranking de los destinos turísticos mediterráneos, detrás de Italia y La Riviera francesa, a pesar de que según Barke y Towner (1996, pp. 8-9) la agencia Thomas Cook no la incluyó en sus giras organizadas hasta 1872. Ni la firma Baedeker, editora de las primeras guías turísticas para europeos, publicó la de España hasta 1898, treinta años más tarde de que hubiera editado las de Suiza e Italia y, lo que es más reseñable, dos años después de las primeras filmaciones realizadas en el país. Esto significa no sólo que la emergencia de España como destino turístico fue lentamente asumida por los agentes de la naciente industria, sino que ella se realizó en paralelo al desarrollo de la producción cinematográfica primitiva. Un dato relevante, si tenemos en cuenta que el cine desde sus mismos orígenes se convirtió en el mayor configurador de imaginarios sociales y en uno de los agentes de la globalización cultural del 
mundo occidental. Es decir, las vistas cinematográficas sobre España no sólo aportarían nuevos perfiles, generalmente imitadores de la imagen fraguada durante siglos por la literatura y las artes, sino que trascenderían los ámbitos de las elites, exclusivas receptoras de la cultura hasta entonces, para alcanzar una difusión universal entre todas las clases sociales.

Analizar hasta qué punto pudieron contribuir esas primeras filmaciones a potenciar el país como destino turístico es una tarea ardua que tropieza con el obstáculo insalvable del deterioro y la pérdida sufridos no sólo por una gran parte de la producción fílmica del cine mudo, sino por muchos de los archivos que contenían datos administrativos de la propia industria, tan necesarios para revelar aspectos relacionados con la distribución, exhibición y recepción de las películas. Sin embargo, pese a la realidad de esa merma, se conservan los suficientes filmes del período como para permitirnos acometer el estudio y el análisis de la situación partiendo de tres cuestiones clave. Me refiero a quién filmaba, qué se filmaba y para qué espectadores. Al respecto, la documentación existente demuestra que, aunque los artífices de las primeras tomas de vistas sobre España empezaron siendo los franceses, un año después compartían esa tarea con otros operadores, españoles y extranjeros, portugueses éstos en su mayoría. Unos y otros, contratados por los exhibidores autóctonos y las productoras extranjeras que empezaban a instalar sus delegaciones en el país, se esforzaron en filmar aquellos asuntos por los que el público mostraba mayor interés y, por tanto, resultaban más vendibles (De la Madrid, 1997).

Partiendo de estas consideraciones, lo que intentaré demostrar a lo largo del texto es que, en la contribución hecha por el cine primitivo español a la configuración del imaginario turístico sobre España, el turolense Segundo de Chomón desempeñó un papel determinante merced a una serie de documentales filmados por él que habrían sido concebidos específicamente con ese objetivo. Para lograrlo voy a servirme del análisis detallado de uno de los más característicos, Burgos, cuyo découpage me permitirá establecer tanto el objetivo que impulsó a su director como los posibles sentidos de su película. En cualquier caso, el uso del análisis textual como método de 
investigación no perderá de vista el contexto histórico en el que surgió el documental y las circunstancias específicas que permitieron en la época el desarrollo de los primeros filmes españoles de tema turístico.

\section{Cine primitivo, pintoresquismo y estereotipos}

Pero vayamos por partes. A semejanza de lo que sucedía en el resto de los países europeos, en España, hacia 1900, fueron las tomas de vistas naturales y urbanas las predominantes. Según la historiadora Palmira González (2005, p. 14), ellas representaban un 21,6\% del total de la producción, mientras las escenas costumbristas, como danzas, corridas y demás festejos populares, sumaban otro 12\%. Esto significa que, por su temática, más de un tercio de las películas filmadas estaba orientado hacia motivos que podían resultar "atractivos turísticos". Por otra parte, el destino de tales filmaciones no sólo era el público español, sino que abarcaba un espectro mucho más amplio, ya que, durante las dos primeras décadas de su historia, el cine traspasó libremente las fronteras nacionales moviéndose con fluidez en una dinámica de intercambios y exportaciones entre países que no era privilegio exclusivo de las potentes productoras francesas, italianas y estadounidenses, cuyas cadenas de distribución cubrían buena parte del territorio mundial. En consecuencia, el ámbito de la recepción era amplio y de carácter internacional.

Por otra parte, al revisar los títulos de esas películas, se comprueba cómo parten de una selección de localizaciones que coinciden básicamente con las que proponían los recorridos turísticos ofrecidos por las agencias. Me refiero al eje Barcelona, Zaragoza, Madrid y Sevilla, ciudades que, además de sus propios atractivos, propiciaban la oportunidad de realizar desplazamientos hacia otras localidades, dada su condición estratégica de nudos ferroviarios. ${ }^{1}$ Cada una de ellas, como núcleo urbano relevante en la geografía nacional, había sido destino tradicional de la cadena de viajeros que durante siglos

\footnotetext{
${ }^{1}$ Las cuatro ciudades eran contempladas por la guía turística Baedeker para su recorrido por España, basado en el trazado ferroviario español. En M. Barke \& J. Towner (1996, p. 9).
} 
venía recorriendo España. Para estos trotamundos la vivencia del viaje equivalía a un rito cultural de iniciación desde el que percibían el mundo como una fuente de aprendizaje y cuya experiencia solía quedar plasmada en ulteriores escritos concebidos para disfrute de la posteridad. Por el contrario, la actitud de los profesionales del cine nada tenía que ver con esa vivencia, sino que viajaban imbuidos por un espíritu radicalmente distinto. En su caso no se trataba de experimentar un descubrimiento de tal o cual lugar, sino de construir una imagen de él lo suficientemente ajustada a las expectativas de los futuros espectadores, aún a costa de falsear determinados datos sobre la realidad.

La constatación de tal actitud la proporcionan unas vistas de 1898 filmadas en la ciudad de Sevilla por la marca Lumière, cuyos títulos Danzas españolas, Procesión en Sevilla, La Feria de Sevilla y Curso de toreo, evidencian un previsible interés por los ritos folclóricos. Sin embargo, el visionado de las imágenes depara algunas sorpresas cuando se comprueba que simulan la anunciada Feria con un mercadillo popular y, lo que es más asombroso, la plaza de toros de la Maestranza con planos del coso francés de Nimes. ${ }^{2}$ Precisamente en razón de su inexactitud se puede calificar a estas vistas de imágenes turísticas, en tanto en cuanto construyen una ficción destinada a colmar las expectativas de sus futuros receptores. ${ }^{3}$ De hecho, se limitaban a abundar en la tendencia que identificaba la realidad sevillana con rituales y prácticas de raigambre decimonónica, como la Feria de abril o el flamenco, asumidos plenamente por los oriundos como sus señas identitarias. De esta forma, la imagen de ciudad romántica definida previamente por pintores y fotógrafos encontraba su natural continuidad en unas vistas filmadas para ser contempladas en todo el mundo (Utrera, 1997, p. 15 y Barrientos, 2010, pp. 27-31). Así, el cine empezaba a configurar el cartel turístico español al seleccionar una iconografía que se convertiría en recurrente y arquetípica para definir no sólo la ciudad de Sevilla, sino toda Andalucía y, por extensión, España, desde una imagen de charanga y

\footnotetext{
${ }^{2}$ Según Begoña Soto (2004, pp. 110-111), tales inexactitudes explicarían el hecho de que estas vistas nunca se proyectaran en Sevilla, a pesar de haber sido anunciadas repetidamente en la prensa.

${ }^{3}$ El sociólogo Marc Augé (1998, p. 16) culpa de esa responsabilidad ficcionalizadora a las agencias de viajes, empeñadas en convertir el mundo en un espectáculo.
} 
pandereta, bailaoras y toreros que habían acuñado los relatos de los numerosos visitantes llegados al sur de la península a lo largo del ochocientos, la literatura de viajes y la novela Carmen de Prosper Merimée, la gran obra mitificadora de España cuyos efectos serían multiplicados por la ópera homónima de Bizet. Esa proclividad de la industria fílmica resultaría más acusada si cabe con el desarrollo de cine argumental, donde sin demasiados escrúpulos se manejaron esos estereotipos insistentemente, y a veces de forma disparatada.

\section{El plus de verdad de Segundo de Chomón}

En paralelo al gusto que se desarrolló por ese pintoresquismo, el interés del turista visitante de España era dirigido por la guía Baedeker hacia otros atractivos culturales, esencialmente relacionados con la herencia artística española, como catedrales, castillos, palacios y colecciones de arte. Todos ellos componían un repertorio obligado sobre el que organizar los recorridos. Y una vez más el cine pareció interesado en asumir la misma estrategia. Sobre todo, a partir de los años diez, cuando las tomas de vistas fueron dando paso a documentales que insistían en mostrar el legado arquitectónico de las ciudades españolas. Al respecto, resultan canónicos los filmados por Segundo de Chomón con títulos tan significativos como Gerona, la Venecia española, La antigua Toledo, Una excursión a la isla de Mallorca y Burgos, entre otros (Quintana, 2010, pp. 254-256). Todos fueron encargados a principios de los años diez por la casa Pathé, de la que Chomón era entonces delegado en Barcelona bajo el paraguas de la marca Ibérico Films creada por la empresa francesa con el objeto de facilitar al turolense las producciones de temas españoles destinadas al mercado internacional (Minguet Batllori, 2010, pp. 132-142). Para esas fechas, el gobierno español ya había dado una respuesta institucional al flujo ininterrumpido de visitantes que llegaban a la península, creando en 1905 la Comisión Nacional de Turismo, que seis años después, en 1911, se transformaría en la Comisaría Regia de Turismo. Con esta estrategia se anticipaba a los mandatarios europeos de su entorno y ponía en evidencia su interés por controlar en la medida de lo posible un fenómeno de masas 
que estaba dando sus primeros pasos, pero en el que se adivinaba un enorme potencial.

Y precisamente de 1911 es Burgos, uno de los filmes ya mencionados, que merece ser comentado con detenimiento. Se trata de una cinta de cuatro minutos de duración coloreada con el sistema Cinemacoloris ideado por el propio Chomón (Tharrats, 1988, pp. 175-176). Consta de dieciocho planos combinados con diez rótulos descriptivos, cuya ubicación y contenido le confieren un neto carácter de documental turístico. Y es que la referencia al viaje queda explícitamente manifiesta desde el mismo título, pues, sin solución de continuidad, tras la palabra Burgos que titula el texto se ha escrito el término Voyage, en alusión intencionada a la vivencia que se pretende suscitar en el público, que no es otra que el disfrute a distancia de una experiencia viajera [F1]. Así, desde ese cartel introductorio,

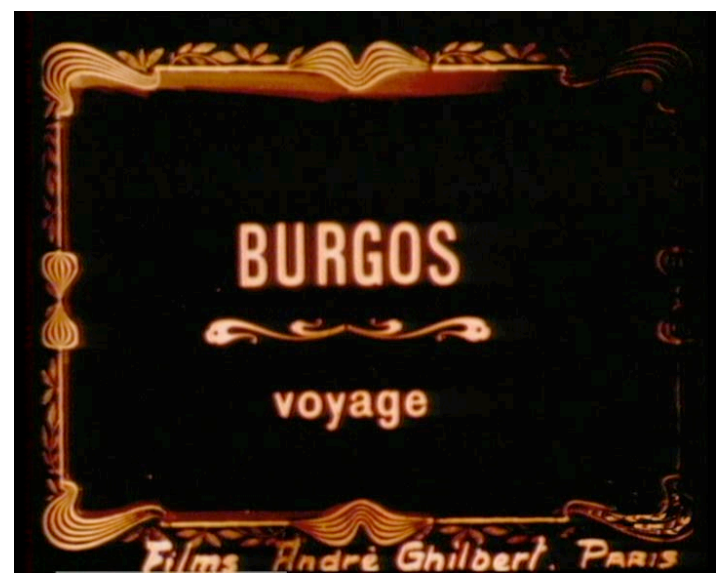
espectador es invitado a conocer la ciudad mediante el acceso a sus lugares emblemáticos, que instantes después le propiciarán las imágenes. Porque toda la estructura narrativa de este documental se ajusta al esquema de una visita turística guiada, de un día de duración, cuya finalidad es recorrer los enclaves significativos de la ciudad hasta la puesta del sol. En realidad, el tiempo diegético del relato queda sintetizado en los cuatro intensos minutos del discurso fílmico. Durante ellos, los espectadores pasearán imaginariamente por un recorrido perfectamente organizado cuyas claves les irán siendo reveladas con la oportuna anticipación mediante la voz narradora que, con el discurso propio de un guía turístico, se deja oír desde los rótulos. El hecho de que, en la copia conservada, ellos estén escritos en francés revela el alcance internacional de los documentales, que, sin duda, Chomón tuvo bien presente. 
En términos descriptivos, a partir del découpage de los veintiocho segmentos del filme, se puede apreciar cómo dicha visita turística comienza con un plano de situación filmado en ángulo alto que muestra una vista general de la ciudad donde las esbeltas torres de la catedral destacan por méritos propios anunciando su protagonismo incuestionable [F2]. Tras él, un rótulo desvela

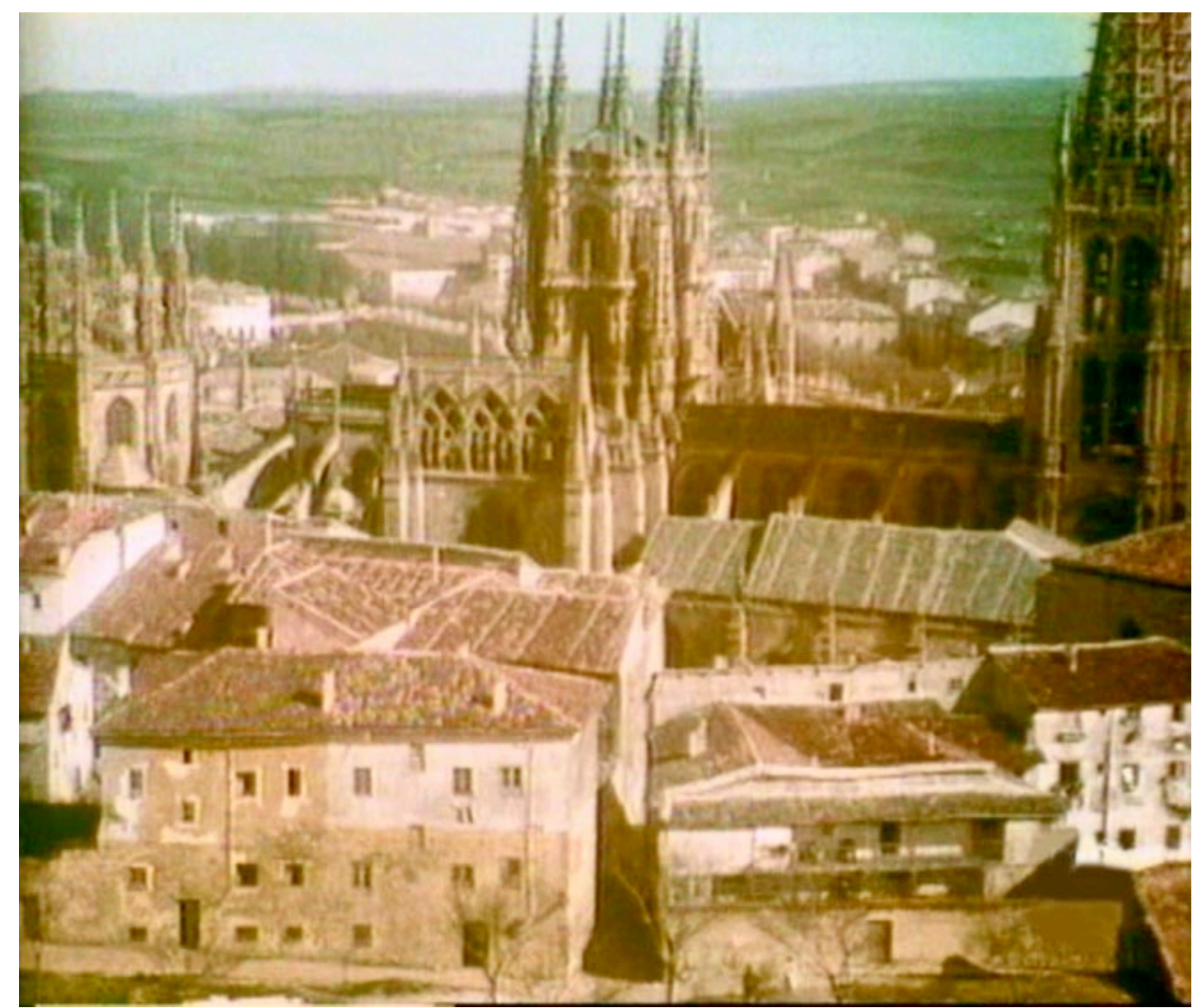

la primera clave cuando advierte de cómo la riqueza artística de Burgos hace de ella una ciudad singular: "Cette ville est une des plus interesantes de l'Espagne, par les monuments qu'elle renferme: L'Église de St. Esteban et la porte du même nom”. El comienzo de la descripción de la ciudad con el monumento de la Iglesia de San Esteban situado extramuros, junto a una de las puertas de la ciudad, permite al cineasta iniciar el recorrido con la lógica propia de un itinerario turístico que se realiza por etapas, en este caso, desde la periferia hacia el centro urbano.

A través de planos hábilmente ordenados, los espectadores, guiados por las imágenes y los rótulos, atraviesan las murallas de la urbe y deambulan por 
sus calles, como lo haría cualquier turista, es decir, observando a los naturales del lugar que encuentran a su paso: un cura, un guardia civil, varias campesinas a lomos de burros y numerosos niños. El desparpajo de este variopinto grupo de personajes al transitar ante la cámara permite adivinar el hábil trabajo de aleccionamiento previo llevado a cabo por el director [F3].

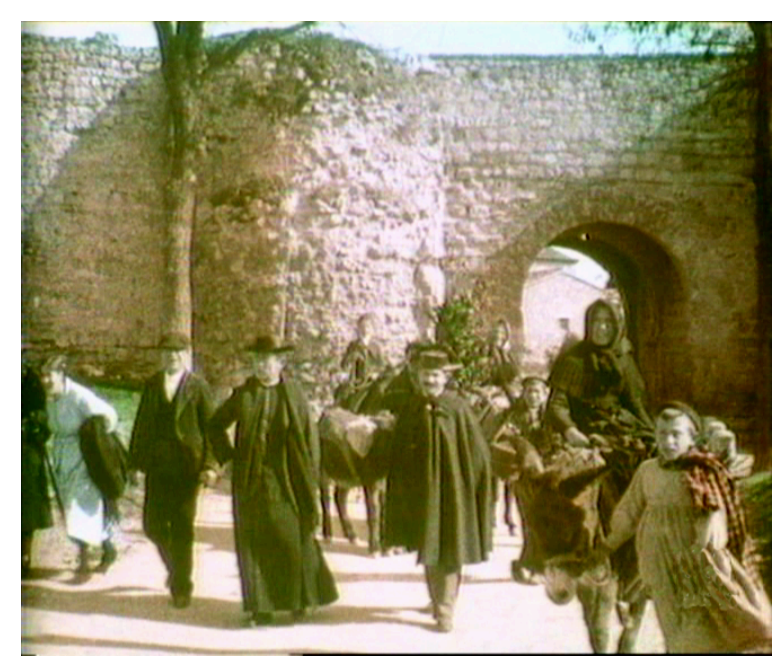
Del mismo modo, la cuidadosa selección de unos tipos humanos tan característicos muestra hasta qué punto Chomón era consciente de cómo debía satisfacer las expectativas de los espectadores extranjeros, cuyo imaginario sobre los modos de vida españoles estaba altamente estereotipado.

Sucesivamente, el monasterio de Las Huelgas, la Plaza de la Libertad y el patio renacentista de la casa del Cordón van haciéndose presentes en el recorrido fílmico hasta llegar al corazón de la villa, donde que se yergue la Catedral [F4]. Y de nuevo, como en las anteriores ocasiones, la voz narradora suena desde los rótulos cual si de un experto guía turístico se tratara, ofreciendo datos precisos referentes a la cronología del monumento y a sus valores artísticos: "La Cathédrale, une des merveilles de l'Espagne, à laquelle on travailla pendant 300 ans" y "Cette cathédrale est surmontée d'un admirable dôme octogonal élevé au-dessus du transept du XVI siècle par FELIPE $\mathrm{DE}$ BORGONA"

(sic). Significativamente, la categoría del edificio es privilegiada por Chomón

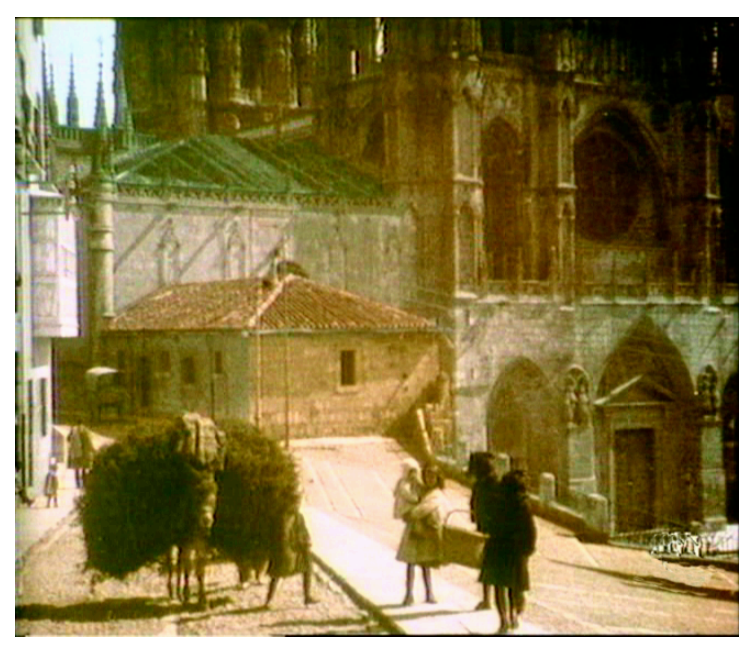
no sólo ubicando sus imágenes en el mismo corazón de la película, sino concediéndole mayor número de planos y rótulos que a los restantes 14 
monumentos -exactamente cuatro planos y dos rótulos-. En términos de práctica turística, tan detenida atención equivaldría a la mayor duración de la visita que la envergadura e importancia del lugar requerirían con respecto a los restantes monumentos de la ciudad.

Desde el relevante enclave catedralicio el documental y sus espectadores inician el camino de regreso a través del Arco de Santa María, la Plaza Mayor y el Paseo de la Isla, hasta acabar retornando al exterior de la ciudad con un plano de la puesta del sol sobre la ribera del río Arlanzón. Así, el final del recorrido viene determinado por el atardecer, que simbólica y convencionalmente clausura también el relato fílmico. Éste, en virtud de su opción por los grandes planos generales donde tienen cabida los soberbios monumentos burgaleses, parece otorgar una atención preferente a la arquitectura de la ciudad, pero sólo es una falsa impresión, porque el elemento humano nunca pasa desapercibido para la cámara, que selecciona y

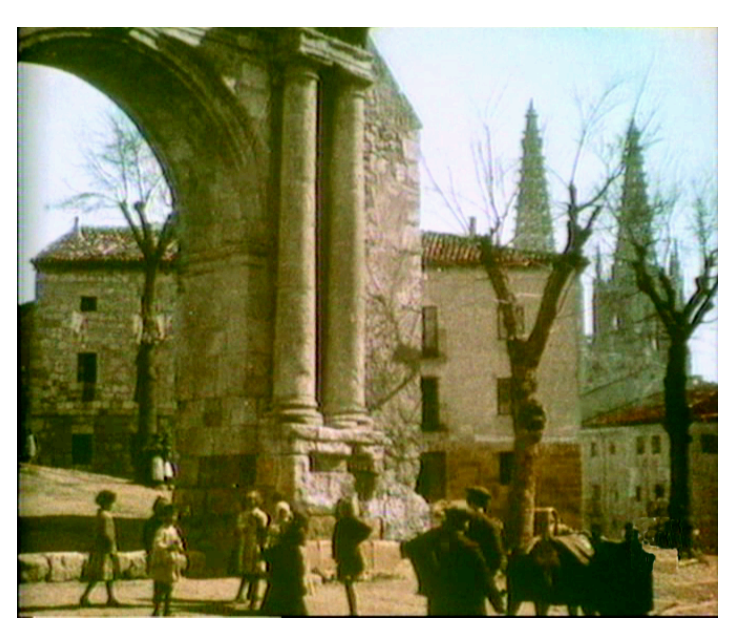
atiende su presencia en el noventa por ciento de los planos. Y es que los espacios abiertos de la villa, sus calles, paseos y plazas, están habitados por una numerosa concurrencia de adultos y niños que corretean de acá para allá ante la mirada curiosa y atenta de una cámara travestida de turista [F5]. Precisamente es la omnipresencia de esos seres anónimos la que permite al relato tomar el pulso a la vida cotidiana de una ciudad como Burgos, cuya condición de capital de provincia y enclave turístico tradicional no le impiden conservar unas formas de vida de perfil mayoritariamente rural, en unos momentos en que los signos de modernidad y cambio, aquí casi imperceptibles, eran ya habituales en otras ciudades españolas. Sin ir más lejos, los automóviles, símbolos de los nuevos tiempos y privilegio exclusivo de las clases acomodadas -cuyo lujo y bienestar quedan reflejados a través de ellos en los melodramas elegantes del cine español coetáneo- (Del ReyReguillo, 2005, pp. 44-46) están ausentes de las calles y plazas mostradas en 
Burgos. Por el contrario, los numerosos carros apiñados en la Plaza de la Libertad [F6] y los burros de carga que recorren la ciudad transportando mercancías y personas insisten en destacar aquella otra España en la que persistían ciertas formas antiguas de vida que servían para caracterizarla como el destino exótico y pintoresco buscado por el turista.

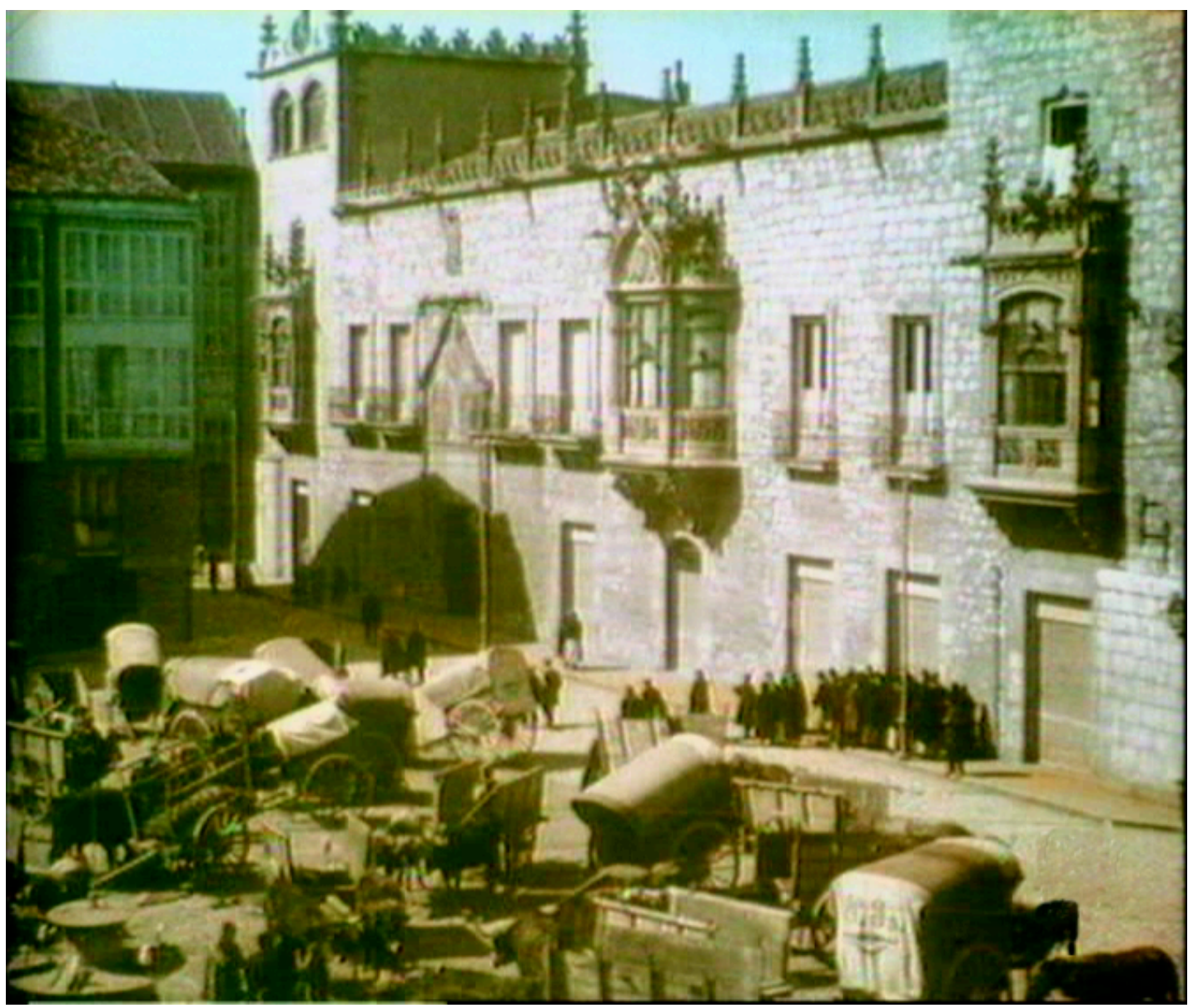

Con todo, el espectador/viajero no tarda en descubrir una nota discordante que rompe el tono del discurso sostenido hasta aquí. Se trata del cochecito de bebé que una niñera empuja mientras camina por el Paseo de la Isla [F7]. La escena corresponde al antepenúltimo plano de la película y parece dedicada a subrayar la quietud melancólica del inminente atardecer, sin embargo, al inscribir en sus márgenes la elegante figura uniformada y, sobre todo, el novedoso cochecito, desvela inopinadamente, y sólo por unos instantes, la existencia de otro Burgos, donde también tienen cabida las pautas de vida consonantes con la modernidad y alejadas de los modos arcaicos y 


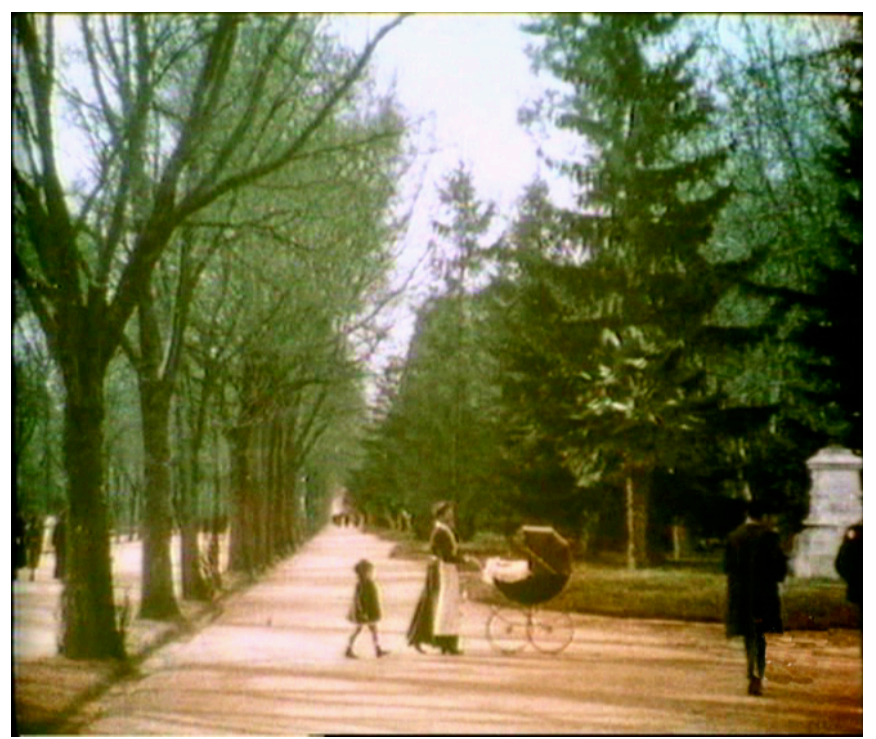

pintorescos tan gratos a la mirada turística (incluso aquella que, como en este caso, se activa por película interpuesta).

Indudablemente, el realizador Chomón, en su tarea de documentalista turístico, privilegió la visión contraria. Por la vía de una cuidadosa operación de selección de motivos y composición de encuadres supo construir un determinado sentido desde el que vincular la ciudad castellana con los usos sociales más tradicionales, mostrándola impasible ante el paso del tiempo, como paralizada bajo el peso de las piedras centenarias de sus monumentos. En cualquier caso, esto no significa que el cineasta claudique en pro del pintoresquismo impostado, sino todo lo contrario, porque las imágenes del turolense están muy lejos de la postal colorista de charanga, pandereta y faralaes que, como iconografía arquetípica, venía manejando el cine para ficcionalizar los tipos y formas de vida españoles. En este sentido, Burgos, sin dejar de funcionar como un reclamo turístico hábilmente diseñado, trasciende la visión estereotipada y reduccionista de España que manejaba la mayor parte del cine extranjero coetáneo y, dotando de autenticidad y vida a cada uno de sus planos, aporta un plus de verdad, una nueva mirada que no es otra que la del observador que conoce y respeta aquello de lo que habla.

\section{Reflexiones finales}

De lo dicho hasta aquí se deduce que durante la etapa que nos ocupa alternaron dos estrategias a la hora de diseñar con imágenes animadas el cartel turístico español. La más frecuente, cuyo ejemplo inaugural fueron las vistas Lumière, fue la de aquellas producciones que abundaban en el tópico construyendo una imagen falseada del país, heredera de la literatura y en 
perfecta concordancia con los prejuicios y apetencias espectatoriales. Frente a ellas, un sentimiento de rechazo e indignación se habría ido extendiendo entre los sectores más cultos de la sociedad española, que acabaron reclamando respuestas contundentes ante tales despropósitos. Precisamente en consonancia con esta actitud se sitúa la segunda estrategia, bien distinta a la anterior, cuyo objetivo es reflejar de forma más fiel la realidad de la España del momento. Esta es la postura que se observa en los documentales de Chomón que, al mostrar mayor diversificación en espacios geográficos y unos tipos humanos más próximos a la realidad de la vida española, habrían servido para corregir y contrarrestar, de alguna manera, la imagen estereotipada ofrecida por la tendencia dominante. Sin embargo, el desinterés que la casa Pathé manifestó por ellos no sólo obligó al realizador a suspender su producción, sino que fue un síntoma evidente de que esta segunda estrategia no triunfaría y el cartel turístico decimonónico de la España pintoresca, folclorista y racial seguiría, durante décadas, marcando las pautas y el interés no sólo del cine extranjero, sino, en buena medida, también del nacional.

Ciertamente, por lo que respecta a los "peliculeros" españoles, esa actitud resultó especialmente notoria en lo referente al cine de ficción, pues durante aquellos años algunos de ellos acabaron asumiendo que los filmes nacionales resultaban más vendibles si se los teñía con el recurrente baño de tipismo, más o menos impostado, y no tardaron poner en marcha unas películas cuyas tramas bebían de los estereotipos sobre lo español para seguir alimentándolos. Era la forma de responder desde la endeble industria cinematográfica española a las competitivas producciones extranjeras que se rodaban en nuestro país, ganándose de paso a los espectadores populares. En este sentido, la valenciana Casa Cuesta fue una de las primeras firmas que adoptaría esa actitud con dos cintas de temas andaluces Los siete niños de Écija o Los bandidos de Sierra Morena (1911-1912) y La lucha por la divisa (1913). Paradigmáticas fueron también, entre otras, La tierra de los naranjos (1914) y Diego Corrientes (1914), ambas producidas por la barcelonesa Hispano Films, de la mano de Albert Marro y Ricardo Baños. Sin embargo, la supuesta buena acogida popular obtenida por aquellas películas, no impidió 
que desde la propia Andalucía se alzaran voces en contra de la imagen folclorista y distorsionada que sobre ella difundían tales producciones. Es lo que sucedió con La otra Carmen, filmada en Córdoba durante el mes de enero de 1915 bajo la dirección de Josep de Togores y Giovanni Doria, cuyo argumento, basado en la novela de Prosper Merimée, contenía tantos lugares comunes -joven aristócrata que se enamora del torero de moda, suicidio por amor, ambientes de fiestas privadas que terminan con peleas a navajazos y corridas de toros donde no faltan las damas "disfrazadas" con sus inevitables vestimentas de majas goyescas- que acabaron por convertirla en el paradigma de todos los defectos y, consecuentemente, en objeto de las más airadas críticas por parte de los diarios locales, que la consideraron una ofensa para las gentes y costumbres de la Andalucía real, a las que en su opinión la película desvirtuaba de modo degradante (Jurado Arroyo, 1997, pp. 56-57).

Aparentemente, el propio Segundo de Chomón tampoco habría podido sustraerse a esa tendencia, al filmar Rêver reveillé o Superstition andalouse (Soñar despierto o Superstición andaluza), única cinta de tema español de las once ficciones que produjo entre 1911 y 1912 en paralelo a los documentales turísticos. Como he señalado en un texto anterior, ya desde su mismo título la película parece apuntar directamente al estereotipo remitiéndonos a un ámbito andaluz donde perviven atavismos tan ancestrales como la superstición (Del Rey-Reguillo, 2008, p. 175). Y el transcurso del relato parece confirmar esa sospecha mediante un argumento en el que se dan cita los celos pasionales de la protagonista, además de un asalto y secuestro perpetrado por bandoleros bajo las órdenes de una vengativa gitana que acaba torturando a su víctima con ardides de bruja. Es decir, los habituales tópicos derivados del imaginario romántico sobre España parecen estar servidos en esta pequeña joya del primer cine español. Con ellos, Chomón se pliega aparentemente a las exigencias marcadas por unas producciones destinadas al consumo exterior. Sin embargo, el genio del turolense, mediante una efectiva argucia del guion, logra deconstruir el aparente significado convencional contenido en su película con una pirueta narrativa que, en los últimos segundos, vuelve el argumento del revés. Solo 
entonces el espectador descubre que la espantosa peripecia sufrida por el protagonista no ha sido tal, sino la engañosa ensoñación sufrida por su enamorada a quien él mismo se encarga de rescatar su pesadilla. Con este giro discursivo el relato no hace sino advertir al espectador sobre la falacia de aquellos estereotipos manejados hasta la saciedad por el cine de la época para dibujar una imagen de España que resultaba tan manida como errónea a esas alturas del siglo XX, cuando la sociedad española estaba experimentando una serie de transformaciones que afectaban a todos los órdenes de la vida pública y privada de sus ciudadanos e implicaban su indiscutible entrada en la modernidad.

Una vez consideradas las estrategias manejadas por Segundo de Chomón en las películas analizadas quedan de manifiesto la maestría y capacidad del realizador que, sin lugar a dudas, sienta las bases del documental turístico español. Por lo que respecta al interés último que parece guiarlas, no resulta descabellado vincular al cineasta con el ideario regeneracionista que inspiraba a las clases ilustradas españolas del momento y suponer que de él era partícipe nuestro personaje. 4 Sólo así se pueden interpretar sus documentales, considerando al director como uno de aquellos españoles clarividentes y emprendedores, cuyas actividades contribuyeron a fomentar la 'industria de atracción de los forasteros', en denominación de la época, al percibirla como una actividad benefactora que no sólo contribuiría al progreso social, sino que podría cambiar la imagen de España en el contexto internacional.

\section{Referencias bibliográficas}

Augé, M. (1998). El viaje imposible. Barcelona: Gedisa. Ayala, F. (1986). La imagen de España. Madrid: Alianza Editorial.

\footnotetext{
${ }^{4}$ Por escasos datos biográficos conocidos sobre la infancia y juventud de Segundo de Chomón sabemos de su condición de último vástago de una saga familiar de médicos, de sus estudios de bachillerato y sus primeras actividades profesionales como escribiente y delineante. Datos todos que permiten situarlo en ámbito de la clase medias española instruida y partícipe del ideario regeneracionista.
}

20 
Barke, M. \& Towner, J. (1996). Exploring the History of leisure and Tourism in Spain. En Barke, M. et al. (eds.), Tourism in Spain. Critical Issues (pp. 3-34). Oxon: Cab International.

Barrientos, M. (2010). Sevilla ante el cinematógrafo. Primeras filmaciones y exhibiciones. En Lahoz Rodrigo, J. I. (Coord.), A propósito de Cuesta. Escritos sobre los comienzos del cine español (1896-1920) (pp. 27-47). Valencia: Ediciones de la Filmoteca.

Dall'Asta, M. (1998). Los primeros modelos temáticos del cine. En Talens, J. \& Zunzunegui, S. (coords.), Historia general del cine (pp. 241-285). Madrid: Cátedra, vol.1.

De la Madrid, J. C. (1997). Primeros tiempos del cinematógrafo en España. Gijón: Ed. Trea.

Del Rey-Reguillo, A. (2005). Los borrosos años diez. Crónica de un cine ignorado (1910-1919), E-excelence - www.liceus.com ISBN: 84-9822$280 X$.

Del Rey-Reguillo, A. (2008). Blasones, tópicos y joyas arquitectónicas para dibujar un país premoderno, en Quintana, A. (Coord.): Cinema $i$ modernitat: les transformacions de la percepció (pp. 171-180). Girona: Fundació Museu del Cinema / Col.lecció Tomàs Mallol.

Friedberg, A. (1993). Window Shopping: Cinema and Postmodernism. Berkeley: University of California Press.

González López, P. (2005). Los inicios del cine en España (1896-19o9): La llegada del cine, su expansión y primeras producciones. E-excelence: www.liceus.com.

Gubern, R. (2004). Del imaginario turístico al imaginario colonial. En Quintana, A. et al. (coords.), Imatge i viatge. De les vistes òptiques al cinema. La configuració de l’imaginari turístic (pp. 23-26). Girona: Fundació Museu del Cinema-Colecció Tomás Mallol / Ajuntament de Girona.

Jurado Arroyo, R. (1997). Los inicios del cinematógrafo en Córdoba. Córdoba: Filmoteca de Andalucía.

Minguet Batllori, J. M. (2010). Segundo de Chomón: el cine de la fascinación. Barcelona: Institut Català de les Indústries Culturals.

Quintana À. (2010). El imaginario turístico del cine primitivo y su función como documento. En Lahoz Rodrigo, J. I. (Coord.), A propósito de Cuesta. Escritos sobre los comienzos del cine español (1896-1920) (pp. 252-257). Valencia: Ediciones de la Filmoteca.

Soto, B. (2004). Usted está aquí. Una reflexión sobre la relación entre las formas de viajar y las imágenes del viaje. En Quintana, A. et al. (coords.), Imatge $i$ viatge. De les vistes òptiques al cinema. La configuració de l’imaginari turístic (pp. 105-113). Girona: Fundació Museu del Cinema-Colecció Tomás Mallol / Ajuntament de Girona. 
Tarrats, J. G. (1988). Los 500 films de Segundo de Chomón. Zaragoza: Universidad de Zaragoza.

Utrera, R. (1997). Presentación. En Utrera, R. (ed.), Imágenes cinematográficas de Sevilla (11-23). Sevilla: Padilla Libros Editores \& Libreros. 